\title{
Purification, characterization and thermostability improvement of xylanase from Bacillus amyloliquefaciens and its application in pre-bleaching of kraft pulp
}

\author{
Sharad Kumar ${ }^{1,2} \cdot$ Izharul Haq $^{1} \cdot$ Jyoti Prakash $^{2}$ - Sudheer Kumar Singh ${ }^{3}$. \\ Shivaker Mishra $^{4}$ Abhay Raj ${ }^{1}$
}

Received: 5 December 2016/Accepted: 8 January 2017/Published online: 11 April 2017

(c) The Author(s) 2017. This article is an open access publication

\begin{abstract}
Xylanases have important industrial applications but are most extensively utilized in the pulp and paper industry as a pre-bleaching agent. We characterized a xylanase from Bacillus amyloliquefaciens strain SK-3 and studied it for kraft pulp bleaching. The purified enzyme had a molecular weight of $\sim 50 \mathrm{kDa}$ with optimal activity at $\mathrm{pH}$ 9.0 and $50{ }^{\circ} \mathrm{C}$. The enzyme showed good activity retention $(85 \%)$ after $2 \mathrm{~h}$ incubation at $50{ }^{\circ} \mathrm{C}$ and $\mathrm{pH}$ 9.0. This enzyme obeyed Michaelis-Menten kinetics with regard to beechwood xylan with $K_{\mathrm{m}}$ and $V_{\max }$ values of $5.6 \mathrm{mg} / \mathrm{ml}$, $433 \mu \mathrm{M} / \mathrm{min} / \mathrm{mg}$ proteins, respectively. The enzyme activity was stimulated by $\mathrm{Mn}^{2+}, \mathrm{Ca}^{2+}$ and $\mathrm{Fe}^{2+}$ metal ions. Further, it also showed good tolerance to phenolics $(2 \mathrm{mM})$ in the presence of syringic acid (no loss), cinnamic acid (97\%), benzoic acid (94\%) and phenol (97\%) activity retention. The thermostability of xylanase was increased by 6.5 -fold in presence of sorbitol $(0.75 \mathrm{M})$. Further, pulp treated with $20 \mathrm{U} / \mathrm{g}$ of xylanase $(20 \mathrm{IU} / \mathrm{g})$ alone and with sorbitol $(0.75 \mathrm{M})$ reduced kappa number by 18.3 and $23.8 \%$,
\end{abstract}

Abhay Raj

araj@iitr.res.in; abhayraj_1@ rediffmail.com

1 Environmental Microbiology Laboratory, Environmental Toxicology Group, CSIR-Indian Institute of Toxicology Research (CSIR-IITR), Vishvigyan Bhavan 31, Mahatma Gandhi Marg, Lucknow, Uttar Pradesh 226001, India

2 Amity Institute of Biotechnology, Amity University, Lucknow Campus, Malhaur, Near Railway Station, Gomti Nagar Extension, Lucknow, Uttar Pradesh 226028, India

3 Microbiology Division, CSIR-Central Drug Research Institute (CSIR-CDRI), Sector 10, Jankipuram Extension, Sitapur Road, Lucknow, Uttar Pradesh 226031, India

4 Environment Management Division, Central Pulp and Paper Research Institute, Post Box 174, Paper Mill Road, Himmat Nagar, Saharanpur, Uttar Pradesh 247001, India respectively after $3 \mathrm{~h}$ reaction. In summary, presence of xylanase shows good pulp-bleaching activity, good tolerance to phenolics, lignin and metal ions and is amenable to thermostability improvement by addition of polyols. The SEM image showed significant changes on the surface of xylanase-treated pulp fiber as a result of xylan hydrolysis.

Keywords Bacillus amyloliquefaciens · Xylanase · Purification · Thermostability - Kappa number - SEM

\section{Introduction}

Plant cell walls contain primarily three organic components, viz. cellulose, hemicellulose and lignin. Xylan is the major part of hemicellulose and a complex polysaccharide composed of a backbone of $\beta$-1, 4-glycoside-linked xylose residues. Due to the complex structure of xylan, its complete degradation requires coordinated action of several hydrolytic enzymes. Among them, xylanases (E.C. 3.2.1.8) play a crucial role in xylan hydrolysis, as it breaks $1,4-\beta-D-$ xylosidic linkages in xylan to give short xylooligosaccharides. The xylanases are under intensive research due to their potential in food, animal feed, pulp and paper, textiles and for biofuel production (Dhiman et al. 2008). Due to emerging environmental concerns associated with chlorine use and toxicity of chlorine-bleached effluents, xylanases emerge as an attractive and environmentally safe alternative for prebleaching of kraft pulp. Its use prior to bleaching of kraft-cooked pulp has been shown reduced chlorine usage.

Most of the industrial processes are carried out at high temperature and $\mathrm{pH}$ in the presence of inhibitors, hence, any xylanase intended to be used for such processes must be robust enough to withstand such conditions (Bajaj and 
Manhas 2012) and should also be produced in a cost-effective manner so that overall cost economics is not altered. Although xylanases are produced by a wide range of different microorganisms, yet bacteria, due to their ability to grow and produce xylanases at high $\mathrm{pH}$ and temperature with minimum or no cellulase production, are widely exploited for xylanase production for industrial applications (Bajaj and Manhas 2012; Dhiman et al. 2008; Raj et al. 2013a). Despite the extensive search for microbial diversity for novel xylanase producers, however, xylanases with thermo and alkali stability are limited (Bajaj et al. 2011) and there remains a strong need for thermostable xylanases. Hence, both approaches requiring exploitation of microbial diversity or by mutagenesis of existing enzymes continue. Apart from this chemical modification, cross-linking, immobilization and treatment with additives have also been tried to improve the properties (Gupta 1991). The addition of polyols to protein solution provides a simple and practical approach for increasing the stability of enzymes. The polyols are thought to promote salt-bridge formation between amino acid residues, which makes the enzyme molecule more rigid and more resistant to thermal unfolding (George et al. 2001; Costa et al. 2002). However, the selection of the appropriate additive depends on the nature of the enzyme. In this study, we carried out purification and characterization of xylanase from Bacillus amyloliquefaciens and studied the effect of polyols on xylanase thermostability and in kraft pulp pre-bleaching.

\section{Materials and methods}

\section{Chemicals and culture media}

Beechwood xylan, 3, 5-dinitrosalicylic acid (DNSA), Congo red, D-xylose, alkali lignin and phenolics were purchased from Sigma (St. Louis, MO, USA). DEAECellulose and sorbitol were from Merck Bioscience. All other chemicals and solvents used in this work were of analytical grade and obtained from S. D. Fine Chem. Ltd., Mumbai, India. Microbiological culture media and media ingredients were obtained from HiMedia (Mumbai, India). The wheat bran (Triticum aestivum) was obtained from the local market in Lucknow (U. P.), India.

\section{Isolation of xylanolytic bacterial isolates}

Xylanolytic bacteria were isolated from the soil sample collected near Star Pulp and Paper Mill, Saharanpur, Uttar Pradesh, India, from the effluent channel. The isolation procedure was as provided: $1 \mathrm{~g}$ soil was added in $9 \mathrm{ml}$ sterile normal saline, vortexed for one min, and $0.1 \mathrm{ml}$ suspension was spread over xylan agar plate and incubated at $37{ }^{\circ} \mathrm{C}$ for $48 \mathrm{~h}$. Xylan agar plates were made using basal medium containing (g/l): $\mathrm{NaNO}_{3} 3.0, \mathrm{~K}_{2} \mathrm{HPO}_{4}$ $0.5, \mathrm{MgSO}_{4} \cdot 7 \mathrm{H}_{2} \mathrm{O} \quad 0.2, \mathrm{MnSO}_{4} \cdot \mathrm{H}_{2} \mathrm{O} \quad 0.02, \quad \mathrm{FeSO}_{4} \cdot \mathrm{H}_{2} \mathrm{O}$ 0.02 , and $\mathrm{CaCl}_{2} \cdot 2 \mathrm{H}_{2} \mathrm{O} 0.02$, agar powder 15.0 and yeast extract 5.0 (Raj et al. 2013a), adjusted to $\mathrm{pH} 7.2$ using $2.0 \% \quad \mathrm{Na}_{2} \mathrm{CO}_{3}$, and $1.0 \%$ beechwood xylan (w/v) as a source of carbon. Distinct colonies observed on xylan agar plate were re-streaked on the nutrient agar plate. The purity of isolates was checked microscopically following Gram's staining.

\section{Screening of xylanase activity}

Qualitative xylanase activity screening test for isolated bacterial isolates was performed by growing individual isolate on xylan agar plate at $37{ }^{\circ} \mathrm{C}$ for $48 \mathrm{~h}$. The plates were stained with $1 \%$ Congo red solution for $15 \mathrm{~min}$ and washed with $\mathrm{NaCl}$ solution $(1 \mathrm{M})$ to visualize xylan hydrolysis zone (Raj et al. 2013a). Quantitative assay of xylanase production was studied in the liquid basal medium by inoculating one loop full bacterial culture in $50 \mathrm{ml}$ basal medium ( $\mathrm{pH} 7.2$ ) containing wheat bran (1\%, $\mathrm{w} / \mathrm{v})$. The flasks were incubated at $37^{\circ} \mathrm{C}$ and $120 \mathrm{rpm}$ agitation. After $48 \mathrm{~h}$ incubation, xylanase activity was quantified in centrifuged culture supernatants. Isolate with the highest xylanase producing ability was selected for further studies.

\section{$16 S$ rRNA gene sequencing}

Genomic DNA was extracted and purified using GeneiPureTM Bacterial DNA purification kit (Merk India). The PCR amplification of the $16 \mathrm{~S}$ rRNA gene was performed using 16S rRNA universal primers: 27F (5-AGAGTTTGATCCTGGCTCAG-3) and 1492R (5-TACGGTTACCTTGTTACGACTT-3) at the annealing temperature of $56{ }^{\circ} \mathrm{C}$ (35 cycles). The task of sequencing was outsourced to $\mathrm{M} / \mathrm{s}$. Amnion Bioscience (Bangalore, India). The 16S rRNA gene sequences of strain SK-3 were compared using NCBI-BLAST against the sequences of bacteria available in databanks (http://www.ncbi.nlm.nih.gov/ ). Program MEGA 6.0 was used to phylogenetic analysis and tree construction using Neighbour-Joining method. Some morphological and biochemical tests were also conducted (Barrow and Feltham 1993).

\section{Time course of bacterial growth and xylanase production}

The study was conducted in liquid culture condition using the xylanase production basal medium containing wheat 
bran as substrate. The bacterium was cultivated in overnight $(18 \mathrm{~h})$ in LB broth under shaking $(120 \mathrm{rpm})$ with an absorbance of 0.6 OD (A600: $1 \mathrm{~cm}$ cuvette) and inoculated $1 \%(\mathrm{v} / \mathrm{v})$ into $500 \mathrm{ml}$ of basal media containing $1.0 \%$ wheat bran. The flasks were incubated at $37^{\circ} \mathrm{C}$ and $120 \mathrm{rpm}$ agitation for $120 \mathrm{~h}$ (Innova, New Brunswick, USA). The culture broth was withdrawn at different time intervals to monitor bacterial cell growth and xylanase/cellulase activities. Cell growth was measured by taking absorbance of culture broth at $620 \mathrm{~nm}$ (UVvisible 2300 spectrophotometer, Techcomp, Korea).

\section{Xylanase assay}

Extracellular xylanase/cellulase activities were assayed by measuring the released reducing sugars formed by enzymatic hydrolysis of beechwood xylan or carboxymethyl cellulose (CMC). The supernatant $(8000 \mathrm{rpm}$ for $10 \mathrm{~min}$, at $4{ }^{\circ} \mathrm{C}$ ) were assayed by procedures described by Raj et al. (2013a). The quantification of the reducing sugars released from both assays was done according to the DNS method developed by Miller (1959), using calibration curve of Dxylose and D-glucose. One unit (IU) of xylanase/cellulase activity was defined as the amount of enzyme that released $1 \mu \mathrm{M}$ of reducing sugars equivalent to D-xylose/D-glucose per min under the assay conditions.

\section{Xylanase purification}

The culture broth was centrifuged ( $8000 \mathrm{rpm}$ for $20 \mathrm{~min}$ ) after $48 \mathrm{~h}$ growth and filtered through $0.45 \mu \mathrm{m}$ filters (Millex Durapore, Millipore) to remove bacterial cells. The culture supernatant $(400 \mathrm{ml})$ was treated with ammonium sulfate $(0-80 \%$ saturation) under constant stirring and was kept refrigerated for $2 \mathrm{~h}$. Afterwards, it was centrifuged and the pellet was dissolved in $0.05 \mathrm{M}$ sodium phosphate buffer ( $\mathrm{pH}$ 8.0) and dialyzed at $4{ }^{\circ} \mathrm{C}$ for overnight against the same buffer using $12 \mathrm{kDa}$ cut-off membrane (Himedia, LA395-5MT). The dialyzed enzyme solutions were pooled, desalted, and concentrated by ultrafiltration using Amicon Ultra-15 $10 \mathrm{kDa}$ (Millipore). Concentrated enzyme (5 ml) was applied to an ion-exchange column $(1.5 \mathrm{~cm} \times 30 \mathrm{~cm})$ packed with DEAE-cellulose ion exchange column equilibrated with the same buffer. Proteins were eluted first with $20 \mathrm{ml} 0.05 \mathrm{M}$ sodium phosphate buffer to remove the unbound proteins and then with a $0.1-1.0 \mathrm{M} \mathrm{NaCl}$ gradient at a flow rate of $30 \mathrm{ml} / \mathrm{h}$. All the steps were carried out at $4-8{ }^{\circ} \mathrm{C}$. The chromatographic elutes were assayed for protein and xylanase activity. The protein concentration was determined either by measuring the absorbance at $280 \mathrm{~nm}$ or Lowry's method using BSA as a standard (Lowry et al. Lowry et al. 1951).

\section{SDS-PAGE and zymography}

The ammonium sulfate precipitated and DEAE-cellulose purified enzymes were concentrated using ultrafiltration (Amicon Ultra-15 $10 \mathrm{kDa}$, Millipore) and used for SDSPAGE zymography (Tseng et al. 2002). Samples (25-30 $\mu \mathrm{g}$ protein) were subjected to SDS-PAGE using $10 \%$ polyacrylamide in the gel. Electrophoresis was carried out using Mini-Gel Electrophoresis unit (Microkin, Techno Source, Mumbai, India). The samples were loaded in duplicate without the addition of $\beta$-mercaptoethanol (Raj et al. 2013a). On completion of electrophoresis, the gel was cut in two parts. One part of the gel was used for Coomassie brilliant blue R-250 staining and the other portion was used for zymography. Zymogram analysis was performed using the basic protocol of Tseng et al. (2002). The gel was washed twice for $30 \mathrm{~min}$ at $4{ }^{\circ} \mathrm{C}$ in $50 \mathrm{mM}$ sodium phosphate buffer ( $\mathrm{pH}$ 7.0) containing isopropanol (25\%). Afterwards, it was incubated in the same buffer solution containing $1.0 \%$ beechwood xylan solution at $37{ }^{\circ} \mathrm{C}$ for $30 \mathrm{~min}$, staining and de-staining of the gel was performed using $0.1 \%$ Congo red and $1 \mathrm{M} \mathrm{NaCl}$, respectively. Decolourization of gel around the protein bands was correlated with enzyme activity. The molecular weight of proteins was determined by comparing them with standard protein marker (BlackBio Biotech India).

\section{Effect of pH and temperature on activity}

Effect of $\mathrm{pH}$ on xylanase activity was estimated by incubating the purified enzyme at $50{ }^{\circ} \mathrm{C}$ for $15 \mathrm{~min}$ in $1.0 \%(\mathrm{w} /$ v) beechwood xylan solution prepared in $100 \mathrm{mM}$ buffer. The buffer solutions used for the study were citrate buffer ( $\mathrm{pH}$ 4.0-6.0), phosphate buffer $(\mathrm{pH}$ 6.0-8.0), tris- $\mathrm{HCl}$ buffer (pH 8.0-9.0), and glycine- $\mathrm{NaOH}$ buffer $(\mathrm{pH}$ 9.0-11.0). The effect of temperature on xylanase activity was determined by incubating the enzyme with $1.0 \%(\mathrm{w} / \mathrm{v})$ beechwood xylan prepared in tris- $\mathrm{HCl}$ buffer ( $\mathrm{pH} 9.0$ ) for $15 \mathrm{~min}$ at $30,40,50,60,70,80,90$, and $100{ }^{\circ} \mathrm{C}$. Thermostability of xylanase was determined by pre-incubating the enzyme between 30 to $80{ }^{\circ} \mathrm{C}$ temperature in tris- $\mathrm{HCl}$ buffer ( $\mathrm{pH} 9.0$ ) for $3 \mathrm{~h}$, afterwards, residual activity was measured at $50{ }^{\circ} \mathrm{C}$.

\section{Kinetic determinations}

The kinetic studies of the enzymes were determined by measuring the initial hydrolysis rate of beechwood xylan at different substrate concentrations $(1-20 \mathrm{mg} / \mathrm{ml})$ prepared in $100 \mathrm{mM}$ tris $-\mathrm{HCl}$ buffer, $\mathrm{pH} 9.0$ at $50{ }^{\circ} \mathrm{C}$ for $10 \mathrm{~min}$. The Michaelis-Menten constant $\left(K_{\mathrm{m}}\right)$, the maximum velocity $\left(V_{\max }\right)$ and $K_{\text {cat }}$ were calculated using 
Lineweaver-Burk plots with the help of Graphpad Prism software7.0 (Lineweaver and Burk 1934).

\section{Effect of metal ions and additives on enzyme activity}

The effects of different metal ions $\left(\mathrm{Mn}^{2+}, \mathrm{Ca}^{2+}, \mathrm{Fe}^{2+}\right.$, $\mathrm{Zn}^{2+}, \mathrm{Mg}^{2+}, \mathrm{Cu}^{2+}$ and $\mathrm{Hg}^{2+}$ ) and additives ( $\beta$-mercaptoethenol, DTT, EDTA and SDS) on xylanase activity were investigated by including them in the reaction mixtures at the final concentration of $2,4,6,8$ and $10 \mathrm{mM}$, respectively. The effect of lignin $(0.25-1.0 \mathrm{mg} / \mathrm{ml})$ and phenolics (syringic acid, benzoic acid and cinnamic acid and phenol) were also investigated at the final concentration of $2 \mathrm{mM}$. The enzyme activity assays were performed at $50{ }^{\circ} \mathrm{C}$ in tris-HCl buffer (pH 9.0). The enzyme activity without metal ions/additives was treated as control and considered as $100 \%$.

\section{Effect of polyols on xylanase thermostability}

Effect of polyols such as sorbitol, mannitol and glycerol on thermostability was studied by adding them in the enzyme assay mixture at the final concentration of $0.5 \mathrm{M}$. The incubation was performed at $70{ }^{\circ} \mathrm{C}$ for $3 \mathrm{~h}$ and aliquots were withdrawn after every $30 \mathrm{~min}$. The residual xylanase activity was assayed under optimum condition $\left(50{ }^{\circ} \mathrm{C}\right.$ and $\mathrm{pH}$ 9.0). The stability of the enzyme was expressed as a percentage of residual activity compared to the initial enzyme activity. The polyol which showed thermostability enhancement was further studied over a concentration ranged from 0.25 to $1.0 \mathrm{M}$ at $70{ }^{\circ} \mathrm{C}$.

\section{Pulp pre-bleaching studies}

Pulp pre-bleaching studies were conducted on hardwood unbleached kraft pulp collected from Star Paper Mill, Saharanpur, (Uttar Pradesh, India). Oven dried unbleached kraft pulp was washed extensively to remove the alkali. The pulp prebleaching studies were performed at $\mathrm{pH} 9.0$ and $60{ }^{\circ} \mathrm{C}$ with a xylanase dose of $20 \mathrm{IU} / \mathrm{g}$ added to oven dried pulp of $10 \%$ consistency and incubated for $3 \mathrm{~h}$ in a water bath under shaking at $100 \mathrm{rpm}$. Pulp prebleaching studies were also conducted in presence of $0.75 \mathrm{M}$ sorbitol. Pulp without enzyme treatment was taken as control. Control and enzyme treated pulp samples were filtered, washed with tap water, and dried in an oven at $70{ }^{\circ} \mathrm{C}$ to a constant weight. Reducing sugars released from untreated and enzyme-treated pulp were measured according to Miller (1959). The release of the phenolics and hydrophobic compounds were measured at 237 and 465 nm, respectively (Gupta et al. 2000; Patel et al. 1993). Kappa number, (lignin content in pulp), was estimated by reaction of pulp with acidified potassium permanganate (TAPPI 1985).

\section{Scanning electron microscopy (SEM) analysis}

Surface morphology of enzyme treated and untreated pulp samples were examined by scanning electron microscope (SEM, QUANTA 450 FEG, FEI, Netherland). Untreated and treated pulp samples are oven dried by incubating at $70{ }^{\circ} \mathrm{C}$ overnight. The samples were placed on a conducting carbon tape over aluminium stubs and coated with platinum in a sputter coater (SC 7620, Quorum Technology Ltd, UK). SEM images of treated and untreated pulp were taken at $1000 \times$ magnifications at an accelerating voltage of $10 \mathrm{kV}$.

\section{Results and discussion}

\section{Isolation and characterization of xylanase producer}

Total five xylanolytic bacterial isolates (named as SK 1-5) were isolated from paper mill effluent contaminated soil. All bacterial isolates formed clear zones on xylan agar plate ranging from 1.3 to $2.5 \mathrm{~cm}$ (data not shown) and produced xylanase utilizing wheat bran as substrates. The mean xylanase production by different isolates ranged from 6.7 to $42.5 \mathrm{IU} / \mathrm{ml}$ after $48 \mathrm{~h}$. Highest xylanase production was recorded for strain SK-3 (42.5 \pm 2.5$)$ followed by SK$2(12.4 \pm 1.6)$, SK-4 (8.8 \pm 1.4$)$ and SK-5 $(6.7 \pm 1.5)$ and SK-1 $(4.5 \pm 1.2)$. Being a highest xylanase producer, strain SK-3 was selected and characterized by 16S rRNA gene sequence analysis. The nucleotide $(1341 \mathrm{bp})$ blast analysis of $16 \mathrm{~S}$ rDNA sequence showed $99 \%$ identity with several Bacillus sp., however, maximum homology (100\%) was observed with Bacillus amyloliquefaciens (Fig. 1). Accordingly, strain SK-3 was named as B. amyloliquefaciens. 16S rDNA sequence has been deposited in NCBI GenBank (Accession no. KU877335). Strain SK-3 was aerobic, rod-shaped gram-positive bacterium and showed a positive reaction for catalase, oxidase, amylase and motility. It was indole negative.

\section{Time course profile of growth and xylanase production by $B$. amyloliquefaciens}

Time-dependent growth and xylanase production study were performed in liquid basal medium $(\mathrm{pH}$ 7.2) containing $1 \%$ wheat bran at $37{ }^{\circ} \mathrm{C}$ and $120 \mathrm{rpm}$ for $120 \mathrm{~h}$. The results showed (Fig. 2) increasing growth and xylanase production by B. amyloliquefaciens strain SK-3 with time. Maximum bacterial growth $\left(\mathrm{OD}_{620 \mathrm{~nm}} 1.6\right)$ and 
Fig. 1 Phylogenetic tree based on a comparison of $16 \mathrm{~S}$ rDNA sequences of xylanaseproducing strain SK-3. The phylogenetic tree was constructed on the aligned datasets using neighbour joining (NJ) method using the program MEGA 6.0. Their names and respective accession numbers are given in the tree

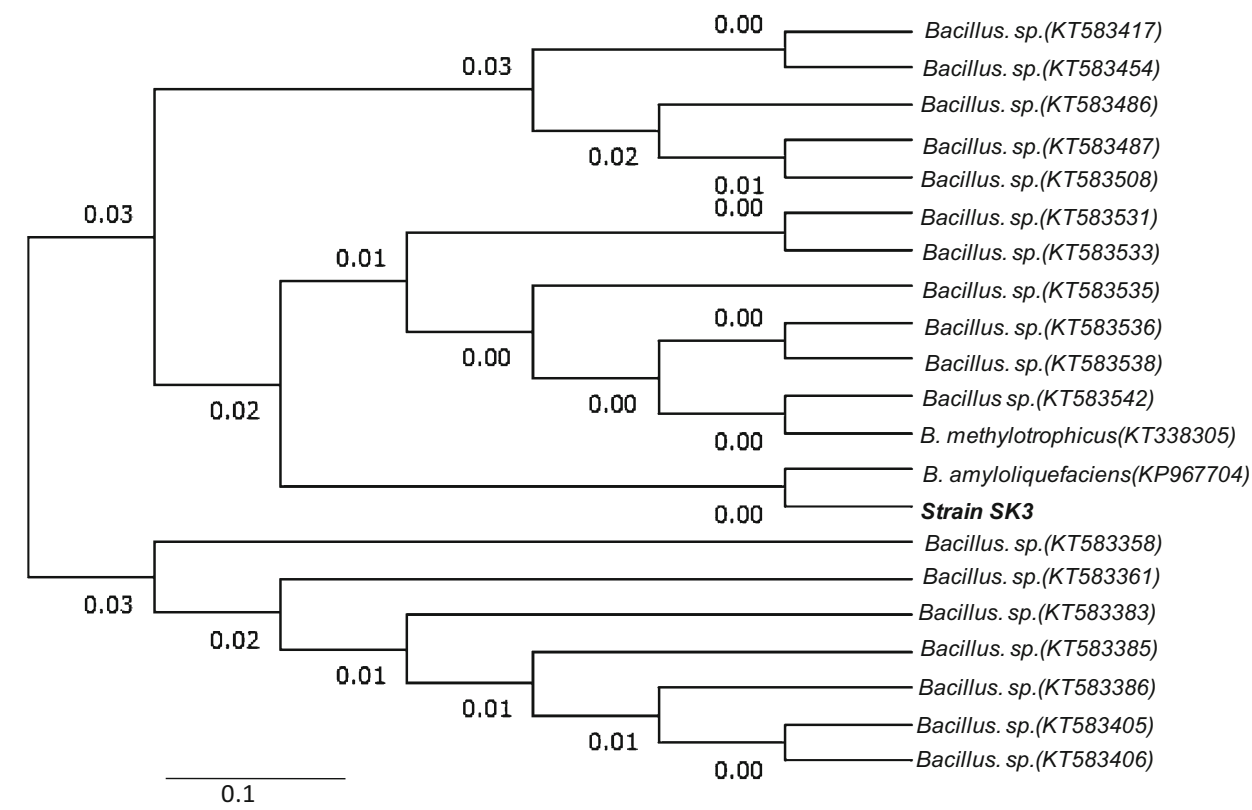

being an agro-industrial residue it helps to bring down the production cost.

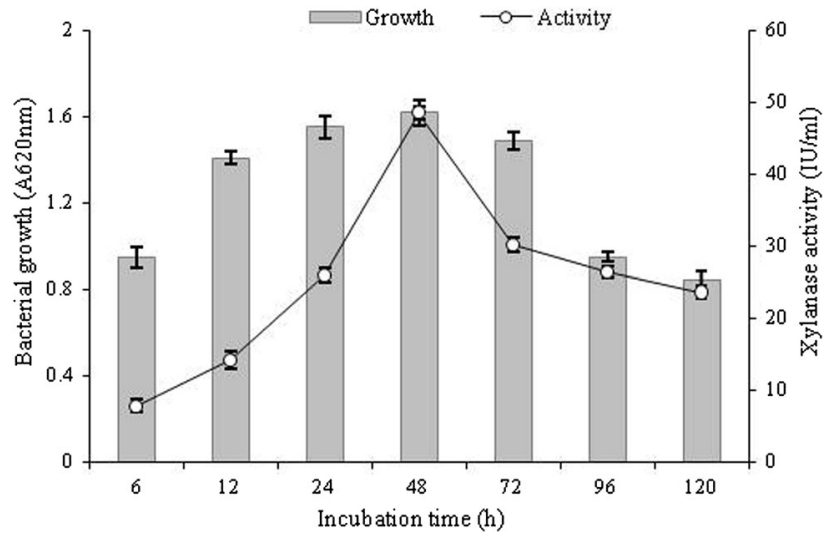

Fig. 2 Time course of growth and xylanase production by $B$. amyloliquefaciens strain SK-3 in basal medium containing wheat bran $(1 \% \mathrm{w} / \mathrm{v})$ at $37^{\circ} \mathrm{C}, 120 \mathrm{rpm}$ and $\mathrm{pH} 7.2$. Experiments were performed in triplicate and results are mean $\pm \mathrm{SD}$ of three values

xylanase activity $(48.5 \pm 1.8 \mathrm{IU} / \mathrm{ml})$ were observed at $48 \mathrm{~h}$. Further, no cellulase activity was determined using $\mathrm{CMC}$ as a substrate. This revealed that B. amyloliquefaciens strain SK-3 xylanase was cellulase-free xylanase. Amore et al. (2015) isolated B. amyloliquefaciens from the soil sample of Western Ghat region and this isolate produced maximum $10.5 \mathrm{U} / \mathrm{ml}$ xylanase on brewer's spent grain substrate after $24 \mathrm{~h}$. Breccia et al. (1998) isolated $B$. amyloliquefaciens from soil sample showed xylanase activity of $10.4 \mathrm{U} / \mathrm{ml}$ on birchwood xylan after $48 \mathrm{~h}$. The production of xylanase by current isolate is significantly higher than those reported earlier. Wheat bran had been used earlier also for both submerged fermentation (SmF) and solid state fermentation (SSF) based xylanase production (Raj et al. 2013b; Sanghi et al. 2010). Wheat bran

\section{Purification of B. amyloliquefaciens xylanase, SDS- PAGE and zymography}

The B. amyloliquefaciens strain SK-3 xylanase purification was performed initially by ammonium sulphate precipitation followed by DEAE-Cellulose chromatography. The xylanase obtained after ammonium sulphate precipitation contained $3.5 \mathrm{mg} / \mathrm{ml}$ protein and showed $295 \mathrm{IU} / \mathrm{ml}$ activity was loaded on DEAE-cellulose column. The eluted fraction numbers 24-26 showing maximum activity were pooled together for further studies. The final purification was 5.06 fold with $22.12 \%$ recovery (Table 1 ). The specific activity was $217.39 \mathrm{IU} / \mathrm{mg}$ protein. There is wide variation in the specific activity of xylanase from different bacterial species. The specific activity of purified xylanase from $B$. amyloliquefaciens strain SK-3 in the present study was higher than the previous reports (Sharma et al. 2013; Bajaj and Manhas 2012; Mishra and Thakur 2010). Kamble and Jadhav (2012) reported xylanase from Bacillus arseniciselenatis strain DSM-15340 having high specific activity of $299.25 \mathrm{IU} / \mathrm{mg}$ protein. However, this is active at neutral pH 8.0.

Xylanase separated by SDS-PAGE gel was treated for enzyme renatuaration (Tseng et al. 2002) followed by zymogram analysis which showed a single protein band corresponding to $\sim 50 \mathrm{kDa}$ with clear decolourisation zone (Fig. 3), suggesting positive xylanase activity of purified protein. The molecular weight (MW) of purified xylanase was comparable to earlier reported xylanase from 
Table 1 Summary of the purification steps of an extracellular xylanase produced by B. amyloliquefaciens strain SK-3

\begin{tabular}{lcccccc}
\hline Purification step & Volume $(\mathrm{ml})$ & Total activity (IU) & Total protein (mg) & Specific activity (IU/mg) & Recovery (\%) & Purification fold \\
\hline Culture filtrate & 400 & 11,300 & 263.50 & 42.88 & 100 & 1.0 \\
Crude AMS & 30 & 8850 & 105.45 & 84.28 & 78.31 & 1.96 \\
DEAE-cellulose & 9 & 2500 & 11.50 & 217.39 & 22.12 & 5.06 \\
\hline
\end{tabular}

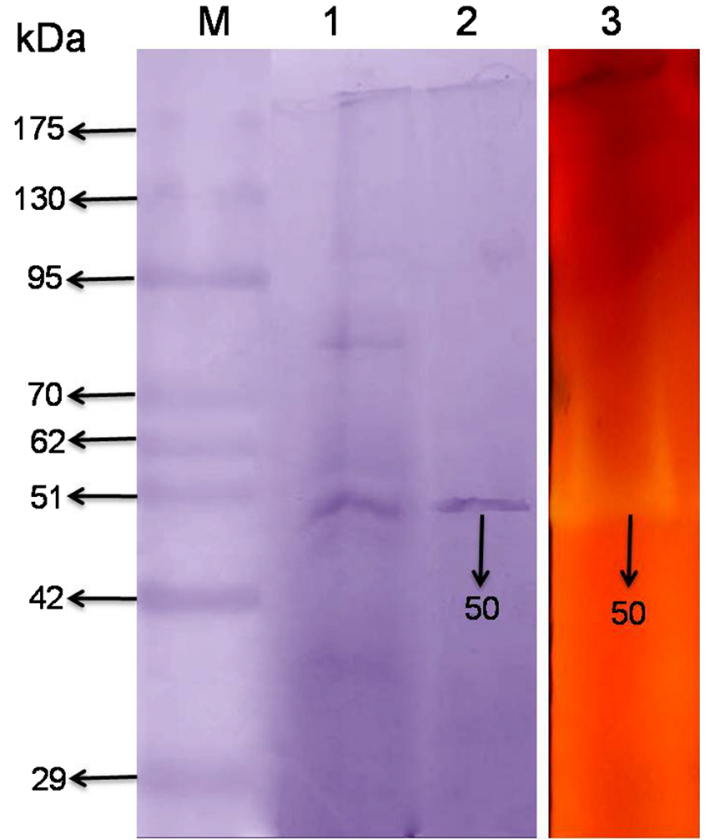

Fig. 3 SDS-PAGE and zymogram analysis of crude and purified $B$. amyloliquefaciens strain SK-3. Lane $M$ protein marker, Lane 1 AMS precipitated crude xylanase and Lane 2 DEAE cellulose purified xylanase. Lane 3 zymogram of DEAE-cellulose purified xylanase

Streptomyces sp. (40 kDa) (Mander et al., 2014). Usually, MW of xylanases reported from different bacteria varies between 20 and $145 \mathrm{kDa}$ (Raj et al. 2013b; Kulkarni et al. 1999) however; a higher MW xylanase (340 kDa) had also been reported (Sá-Pereira et al. 2002).

\section{Biochemical properties of purified xylanase}

The activity of the purified xylanase at different $\mathrm{pH}$ values and at $50{ }^{\circ} \mathrm{C}$ temp is shown in Fig. 4a. The optimum xylanase activity was at $\mathrm{pH} 9.0$, while it showed good activity retention at 66 and 56\% at pH 10 and 11, respectively. These results are consistent with those reported for xylanases from S. maltophilia and B. halodurans (Raj et al. 2013b; Kumar and Satyanarayana 2011). Although xylanases with optimum activity at $\mathrm{pH} 9.0$ had been reported earlier; however, significant activity losses were observed at higher pH (Bajaj and Manhas 2012; Nakamura et al. 1993). The xylanase being reported in this study is superior
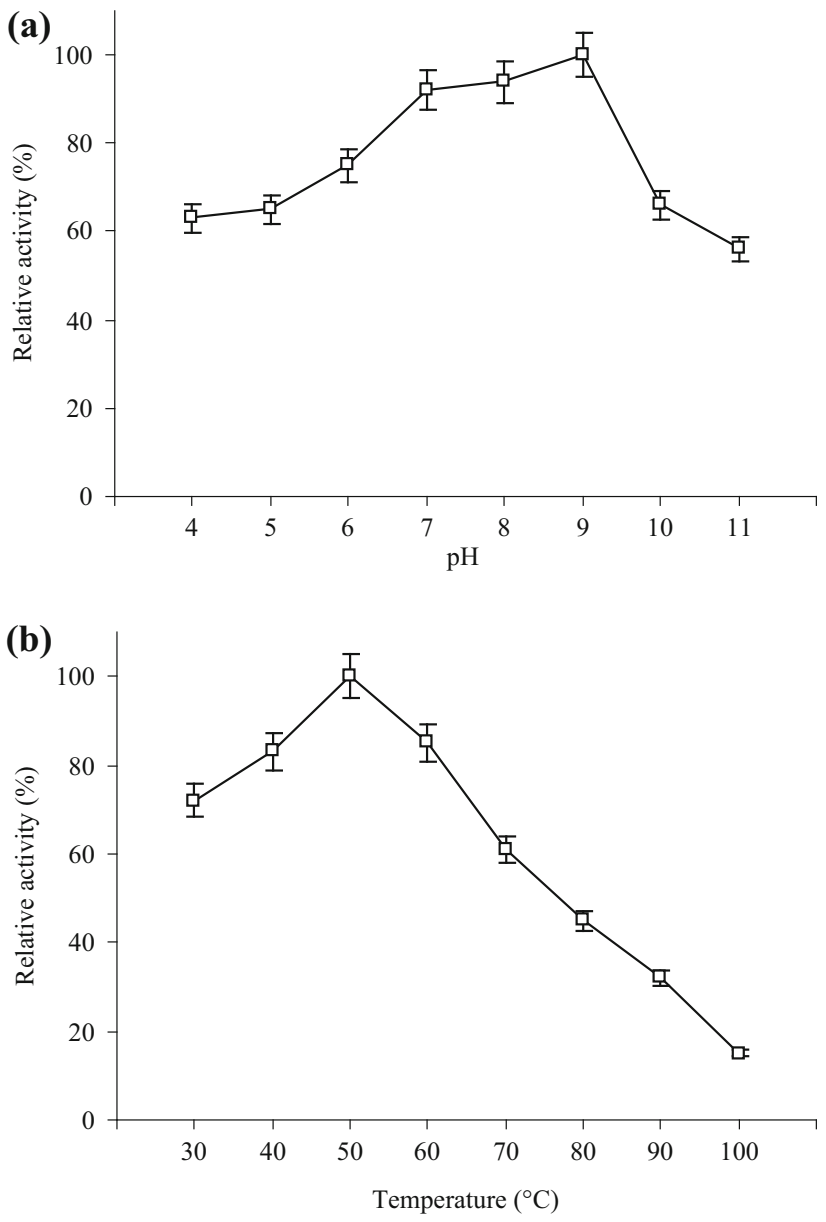

Fig. 4 Optimum $\mathrm{pH}$ (a) and temperature (b) for the activity of purified xylanase from $B$. amyloliquefaciens strain SK-3. Experiments were performed in triplicate and results are mean $\pm \mathrm{SD}$ of three values

in its activity retention compared to earlier reported xylanases.

The activity at different temperatures at $\mathrm{pH} 9.0$ is shown in Fig. 4b. The enzyme shows activity at different temperatures with optimum being at $50{ }^{\circ} \mathrm{C}$. Almost 85 and $61 \%$ activity was observed at 60 and $70{ }^{\circ} \mathrm{C}$, respectively. Similar temperature optimum of $50{ }^{\circ} \mathrm{C}$ was observed for xylanase from Bacillus sp. (Nakamura et al. 1993).

Thermostability of xylanase was evaluated by pre-incubating the enzyme at the temperature ranging from 30 to $80{ }^{\circ} \mathrm{C}$ at pH 9.0 for $180 \mathrm{~min}$ (Fig. 5). The enzyme showed 


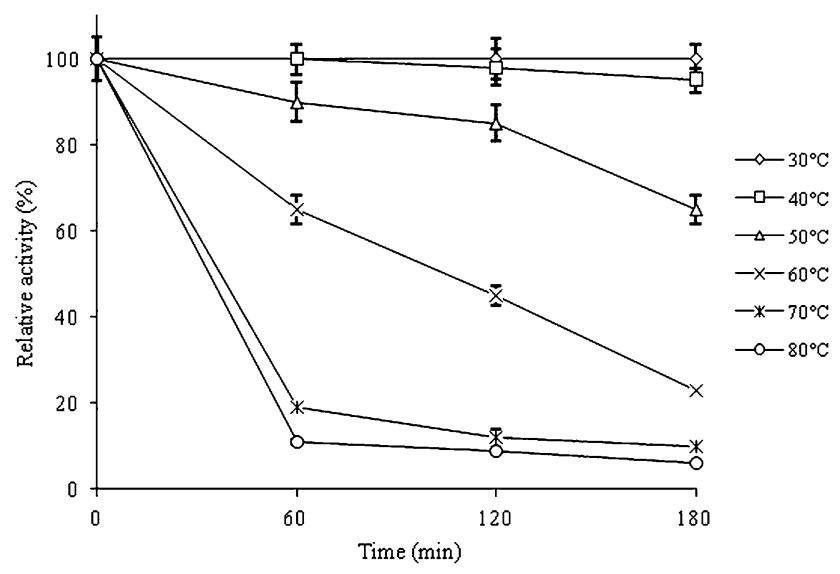

Fig. 5 Thermostability of the purified xylanase from B. amyloliquefaciens strain SK-3 at different temperatures at $\mathrm{pH}$ 9.0. Experiments were performed in triplicate and results are mean $\pm \mathrm{SD}$ of three values

approximately $65 \%$ activity retention was observed at $50{ }^{\circ} \mathrm{C}$ after $180 \mathrm{~min}$ of exposure. Also, at 70 and $80{ }^{\circ} \mathrm{C}$, it retained 10 and $6 \%$ activity (Fig. 5). The loss of enzyme activity throughout the elevated temperature ranges is related to changes of the enzyme conformation (Cui et al. 2008). These results are consistent with thermal stabilities of other bacterial xylanases reported in the literature. Xylanase from Bacillus sp. strain 41-M1 showed 90\% loss of the activity after $30 \mathrm{~min}$ incubation at $60{ }^{\circ} \mathrm{C}$ and $\mathrm{pH} 9.0$ (Nakamura et al. 1993), while xylanase from Bacillus sp. VI-4 retained approximately $15-20 \%$ activity at $60{ }^{\circ} \mathrm{C}$ and pH 9.0 after 30 min incubation (Yang et al. 1995). In comparison, xylanase from present study shows a better thermostability profile with 65,45 and $23 \%$ activity retention at $60{ }^{\circ} \mathrm{C}$ after 60,120 , and 180 min incubation.

The $K_{\mathrm{m}}, V_{\max }$ and $K_{\text {cat }}$ values were determined by the Lineweaver-Burk double reciprocal plot using different concentration of beechwood xylan as substrate and maximum activity was observed in $10 \mathrm{mg} / \mathrm{ml}$ concentration (data not shown). The determined $K_{\mathrm{m}}, V_{\mathrm{max}}$ and $K_{\text {cat }}$ values of the enzyme were $5.6 \mathrm{mg} / \mathrm{ml}, 433 \mu \mathrm{M} / \mathrm{min} / \mathrm{mg}$ proteins and $106.1\left(\mathrm{~min}^{-1}\right)$ respectively. The $K_{\mathrm{m}}$ value for the xylanase is low which shows that the xylanase has better affinity with substrate beechwood xylan substrate. The $K_{\mathrm{m}}$ and $V_{\max }$ value of the enzyme were $4.4 \mathrm{mg} / \mathrm{ml}$ and 287 U/mg from Bacillus sp. (Mishra and Thakur 2010). Sanghi et al. (2010) also reported that the $K_{\mathrm{m}}$ and $V_{\max }$ in birch wood xylan were $3.33 \mathrm{mg} / \mathrm{ml}$ and $100 \mathrm{IU} / \mathrm{ml}$ respectively from Bacillus subtilis ASH.

The effects of various metal ions and additives at the different concentration on xylanase activity are summarized in Table 2. Metal ions $\mathrm{Mn}^{2+}, \mathrm{Ca}^{2+}$ and $\mathrm{Fe}^{2+}$ showed different levels of stimulatory effects on the activity of the xylanase, and the stimulatory effects were gradually enhanced with increasing concentrations. The relative activity of xylanase was shown to be enhanced up to 40 and $45 \%$ by $\mathrm{Mn}^{2+}, \mathrm{Ca}^{2+}$, respectively at $10 \mathrm{mM}$. No significant effects on enzyme activity were observed in presence of $\mathrm{Zn}^{2+}$ and $\mathrm{Mg}^{2+}$ ions at each concentration. However, xylanase activity was strongly inhibited by $\mathrm{Cu}^{2+}$ and $\mathrm{Hg}^{2+}$ in a dose-dependent manner and causing 78 and $88 \%$ inhibition at $10 \mathrm{mM}$. The inhibition or stimulation of enzyme activity may be due to metal ions interaction with $\mathrm{SH}$ or carboxyl groups which led to an altered

Table 2 Effect of different metal ions and additives on activity of purified xylanase from B. amyloliquefaciens strain SK-3

\begin{tabular}{|c|c|c|c|c|c|}
\hline \multirow[t]{2}{*}{ Additive metal ions } & \multicolumn{5}{|c|}{ Relative xylanase activity (\%) } \\
\hline & $2 \mathrm{mM}$ & $4 \mathrm{mM}$ & $6 \mathrm{mM}$ & $8 \mathrm{mM}$ & $10 \mathrm{mM}$ \\
\hline None & $100 \pm 1.2$ & $100 \pm 1.6$ & $100 \pm 2.7$ & $100 \pm 1.6$ & $100 \pm 1.5$ \\
\hline $\mathrm{Mn}^{2+}$ & $120 \pm 2.5$ & $126 \pm 2.0$ & $130 \pm 2.2$ & $135 \pm 2.6$ & $140 \pm 1.8$ \\
\hline $\mathrm{Ca}^{2+}$ & $116 \pm 1.5$ & $120 \pm 1.8$ & $124 \pm 2.4$ & $131 \pm 2.6$ & $145 \pm 1.4$ \\
\hline $\mathrm{Fe}^{2+}$ & $102 \pm 2.0$ & $102 \pm 1.0$ & $105 \pm 1.6$ & $108 \pm 2.4$ & $110 \pm 2.0$ \\
\hline $\mathrm{Zn}^{2+}$ & $95 \pm 1.6$ & $94 \pm 0.8$ & $92 \pm 1.2$ & $90 \pm 1.6$ & $88 \pm 1.4$ \\
\hline $\mathrm{Mg}^{2+}$ & $94 \pm 1.8$ & $92 \pm 1.4$ & $92 \pm 1.8$ & $90 \pm 1.1$ & $90 \pm 0.9$ \\
\hline $\mathrm{Cu}^{2+}$ & $68 \pm 1.4$ & $60 \pm 1.2$ & $54 \pm 2.1$ & $37 \pm 0.8$ & $22 \pm 1.0$ \\
\hline $\mathrm{Hg}^{2+}$ & $60 \pm 0.6$ & $52 \pm 0.8$ & $44 \pm 1.0$ & $30 \pm 0.8$ & $12 \pm 1.2$ \\
\hline \multicolumn{6}{|l|}{ Inhibitors } \\
\hline None & $100 \pm 1.2$ & $100 \pm 1.6$ & $100 \pm 2.2$ & $100 \pm 1.8$ & $100 \pm 1.2$ \\
\hline$\beta$-Mercaptoethanol & $105 \pm 2.8$ & $109 \pm 2.2$ & $118 \pm 1.8$ & $125 \pm 2.0$ & $134 \pm 1.4$ \\
\hline DTT & $102 \pm 1.2$ & $106 \pm 1.8$ & $108 \pm 2.0$ & $110 \pm 1.6$ & $114 \pm 1.4$ \\
\hline EDTA & $75 \pm 0.6$ & $71 \pm 0.8$ & $65 \pm 0.4$ & $55 \pm 0.6$ & $42 \pm 0.9$ \\
\hline SDS & $80 \pm 1.2$ & $75 \pm 1.6$ & $64 \pm 1.8$ & $52 \pm 1.0$ & $32 \pm 1.4$ \\
\hline
\end{tabular}


conformation of protein subsequent inactivation (Nagar et al. 2012). Lee et al. (2008); Park and Cho (2010) reported the stimulatory effect of $\mathrm{Mn}^{2+}$ and $\mathrm{Ca}^{2+}$ on xylanase of $B$. licheniformis and Paenibacillus sp. strain $\mathrm{K} 1 \mathrm{~J} 1 . \mathrm{Hg}^{2+}$ and $\mathrm{Cu}^{2+}$ have previously been reported to strongly inhibit the activity of xylanase from $B$. licheniformis and B. pumilus (Bajaj and Manhas 2012; Nagar et al. 2012). Inhibition by $\mathrm{Hg}^{2+}$ ions may be due to its interaction with sulphydril groups, suggesting that there is an important cysteine residue in or close to the active site of the enzyme (Bastawde 1992). Metal ion $\mathrm{Cu}^{2+}$ has a strong affinity for amino acids and carboxyl groups and may affect the enzyme activity by its interactions with these groups (Sanghi et al. 2010; Menon et al. 2010). $\beta$ Mercaptoethanol and DTT also stimulated xylanase activity and stimulation was dose-dependent. This stimulation of enzyme activity in the presence of DTT (34\%) and $\beta$ mercaptoethanol $(14 \%)$ could be due to the protection of oxidation of sulfhydryl groups (Knob and Carmona 2009). EDTA and SDS showed strong inhibitory effects on xylanase activity in a dose-dependent manner and causing 58 and $68 \%$ inhibition at $10 \mathrm{mM}$. The activity inhibition by a metal chelator (EDTA), indicating that the enzyme requires metal ions for its action (Knob and Carmona 2009). Inhibition of xylanase activity by SDS suggests presence of hydrophobic interactions in maintaining xylanase structure. Similar to our results, the xylanase activity of Paenibacillus campinasensis G1-1 was inhibited in presence of EDTA and SDS with increasing concentrations (Hongchen et al. 2012).

Kraft pulp contains residual lignin which may affect xylanase activity hence; effect of lignin on xylanase activity was studied in a concentration range of $0.25-1.0 \mathrm{mg} / \mathrm{ml}$ (Table 3 ). No effect of lignin on activity was observed at lower lignin concentration $(0.5 \mathrm{mg} / \mathrm{ml})$.

Table 3 Effect of lignin and phenolics on activity of purified xylanase from B. amyloliquefaciens strain SK-3

\begin{tabular}{lc}
\hline Compounds & Relative xylanase activity $(\%)$ \\
\hline Lignin $(\mathrm{mg} / \mathrm{ml})$ & \\
None & $100 \pm 0.8$ \\
0.25 & $100 \pm 0.8$ \\
0.50 & $100 \pm 2.0$ \\
0.75 & $92 \pm 1.0$ \\
1.0 & $90 \pm 0.8$ \\
Phenolics $(2 \mathrm{mM})$ & \\
None & $100 \pm 0.4$ \\
Syringic acid & $106 \pm 0.5$ \\
Benzoic acid & $94 \pm 1.5$ \\
Cinnamic acid & $97 \pm 1.8$ \\
Phenol & $97 \pm 1.3$ \\
\hline
\end{tabular}

However, higher concentrations caused partial inhibition of the enzyme activity and almost 92 and $90 \%$ of its original activity was retained at 0.75 and $1.0 \mathrm{mg} / \mathrm{ml}$, respectively. An earlier study by Morrison et al. (2011) to study the effect of soluble lignin on xylanase activity observed $25 \%$ inhibition at low lignin concentration of $0.075 \mathrm{mg} / \mathrm{ml}$. However, Kaya et al. (2000) observed an increased xylanase mediated hydrolysis $(20 \%)$ with increasing lignin concentration $(0-0.06 \%)$. The kraft pulp contains trace amounts of low molecular weight phenolics which may affect the enzyme activity. The phenolic compounds can be coming from either lignin degradation or are naturally present in plants. Xylanase activity in presence of different
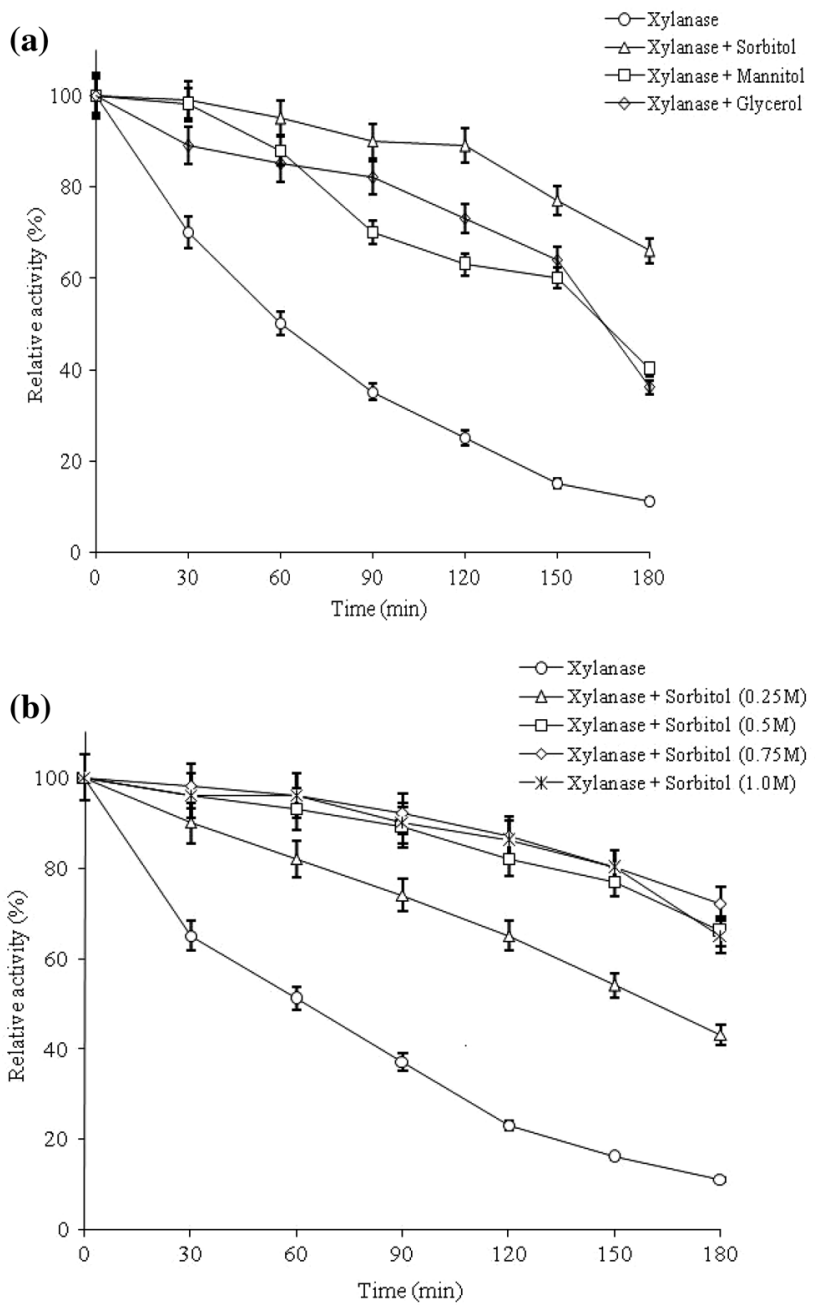

Fig. 6 Effect of polyols on thermostability of the purified xylanase from $B$. amyloliquefaciens strain SK-3 cultivated in basal medium containing $1 \%$ wheat bran. a The enzyme solutions were preincubated in presence of sorbitol, mannitol and glycerol at concentration of $0.5 \mathrm{M}$ prior to enzyme assay. b The enzyme solutions were incubated under same condition as in (a) with presence of sorbitol of $0.25,0.5,0.75$ and $1.0 \mathrm{M}$ prior to enzyme assay at optimal conditions. Experiments were performed in triplicate and results are mean \pm SD of three values 
(a)

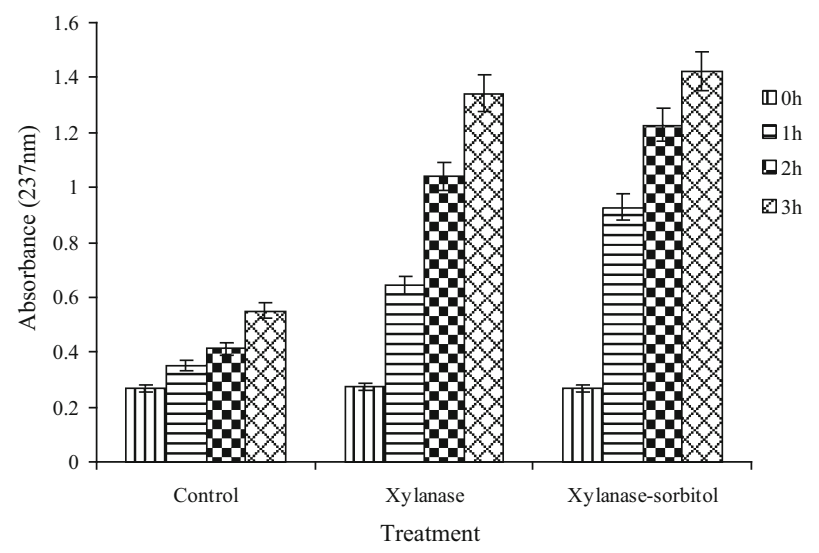

(c)

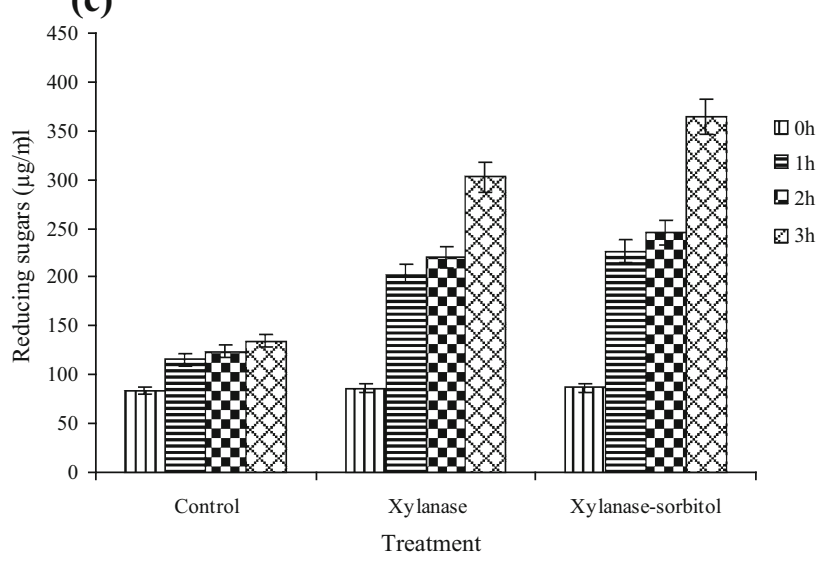

(b)
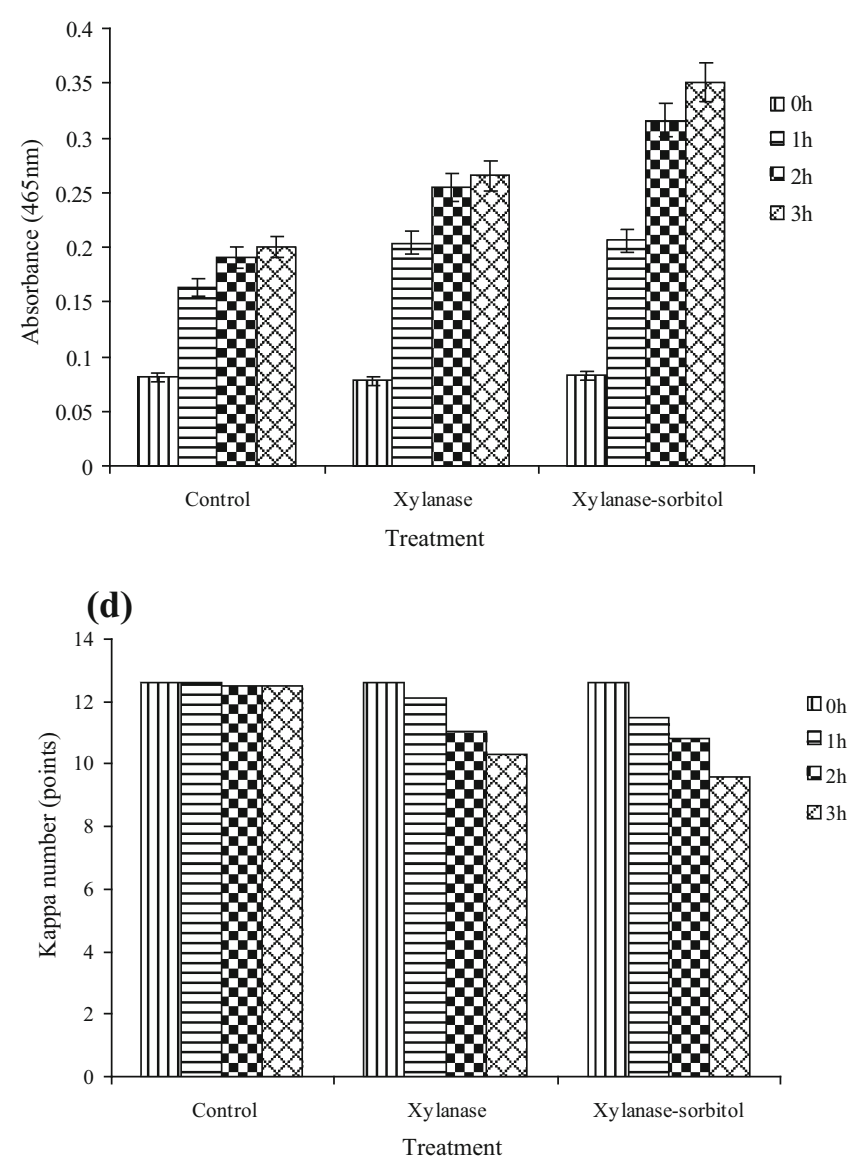

Fig. 7 Effect of the xylanase pre-bleaching on the release of hydrophobic compounds (a), phenolic compounds (b), reducing sugars (c) and kappa number reduction (d) of kraft pulp. Experiments were performed in triplicate and results are mean \pm SD of three values

phenolic compounds $(2 \mathrm{mM})$ is presented in Table 3. Slight increase in xylanase activity in the presence of syringic acid and a decrease with benzoic acid, cinnamic acid and phenol was observed. Inhibition of xylanase activity was reported by Morrison et al. (2011) in presence of coumaric acid and gallic acid.

\section{Effect of polyols on xylanase thermostability}

It was found that purified xylanase was quite stable (retaining 65\%) at least for $180 \mathrm{~min}$ at $50{ }^{\circ} \mathrm{C}$ and $\mathrm{pH} 9.0$. In order to avoid this thermal inactivation, thermostability of xylanase in the presence of $0.5 \mathrm{M}$ sorbitol, mannitol and glycerol were investigated at $70{ }^{\circ} \mathrm{C}$. Figure 6 a shows that all sugars have increased the stability of xylanase by several folds over control. The highest stability increase was observed in the presence of sorbitol (6.0-fold) followed by mannitol (3.6-fold) and glycerol (3.3-fold) after $180 \mathrm{~min}(3 \mathrm{~h})$ and compared activity in control (11\%), enzyme provided with polyols retained almost 66,40 and
$36 \%$ of its original activity in the presence of sorbitol, mannitol and glycerol, respectively. Also, a concentration dependent effect of sorbitol on activity was observed (Fig. 6b) and in the presence of 0.25, 0.5, 0.75 and $1 \mathrm{M}$ sorbitol, an increase of 3.9, 6.0, 6.5, and 5.9 fold xylanase activities was observed over control after $3 \mathrm{~h}$ incubation at $70^{\circ} \mathrm{C}$. Earlier studies had also reported a positive effect of sorbitol on xylanases stability (George et al. 2001; Khandeparkar and Bhosle 2006; Bankeeree et al. 2014). The Phenomenon of protein stabilization by polyols may be due to changes in enzyme microenvironment resulting in a more rigid conformation of the enzyme (Lemos et al. 2000). The stabilizing effect of additives is not an absolute effect valid for all enzymes, and depends on the nature of the enzyme, on its hydrophilic and hydrophobic character and on the degree of interaction with the additive (George et al. 2001). However, the improvement of xylanase stability in the presence of sorbitol suggests its applicability in the pulpbleaching process.

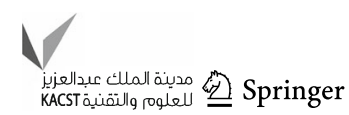



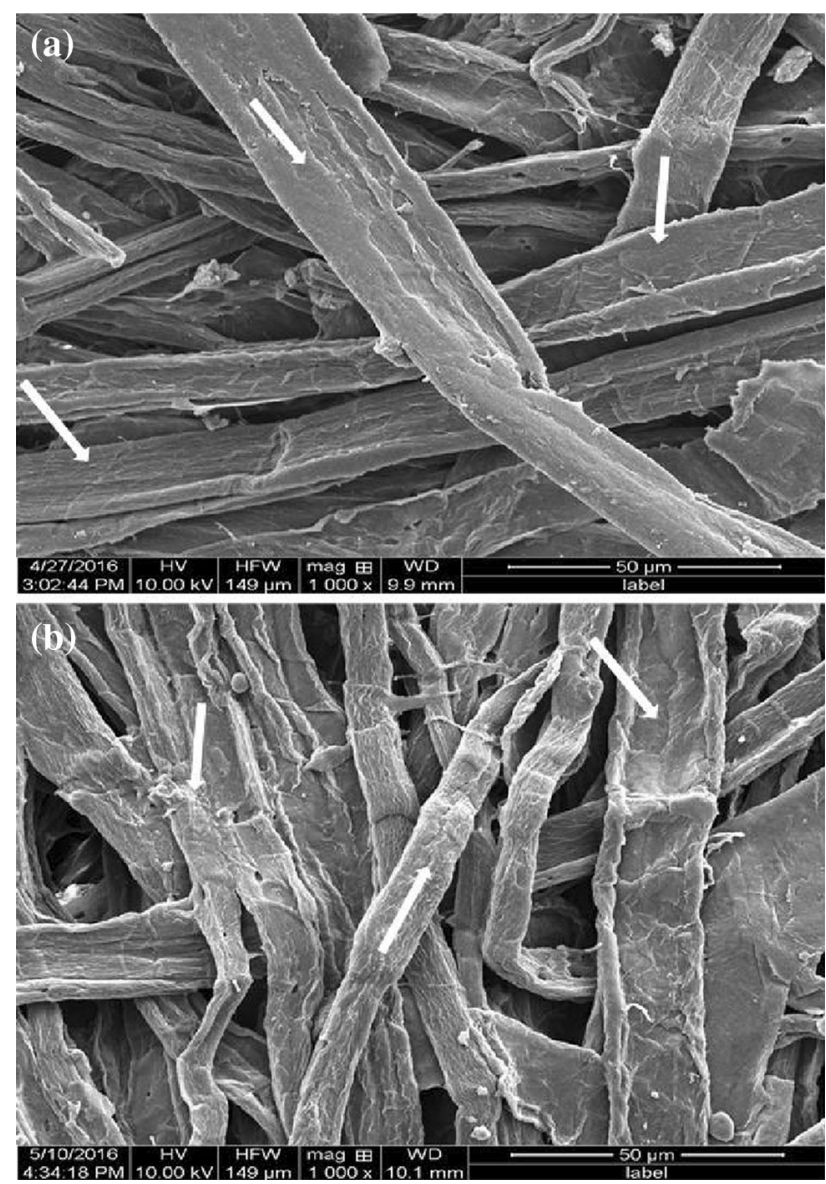

Fig. 8 SEM images of the untreated (a) and xylanase treated (b) pulp fiber at $\times 1000$ magnification

\section{Pre-bleaching of kraft pulp}

The effect of xylanase on kraft Pulp pre-bleaching studies was performed using purified xylanase added with and without sorbitol $(0.75 \mathrm{M})$ at $60{ }^{\circ} \mathrm{C}$ and $\mathrm{pH}$ 9.0. Details about the release of reducing sugars, phenolics and other hydrophobic compounds and reduction of kappa number at different time points are presented in Fig. 7. The filtrate of pulp treated with xylanase and xylanase-sorbitol mix had 2.4, 2.6 and 1.3, 1.8 fold higher phenolic and hydrophobic compounds, respectively than the filtrate of xylanase untreated pulp (Fig. 7a, b). The amount of reducing sugar was treatment time dependent. The initial amount of reducing sugars in the filtrate of untreated pulp was $135 \mu \mathrm{g} / \mathrm{ml}$. The reducing sugar content after treatment with xylanase and xylanase-sorbitol increased to 302.1 and $364.2 \mu \mathrm{g} / \mathrm{ml}$, respectively (Fig. 7c). This increase in reducing sugars content correlates positively with xylanase mediated xylan degradation. Kappa number, which measures the amount of lignin present in the pulp was 12.6 for untreated pulp. After treating it with $20 \mathrm{U} / \mathrm{g}$ of xylanase and xylanase-sorbitol, it decreased to 10.3 and 9.6, respectively after $3 \mathrm{~h}$. This suggests a decrease of 18.3 and $23.8 \%$ of kappa number after treatment with xylanase and xylanase-sorbitol, respectively (Fig. 7d). The release of phenolics and hydrophobic compounds and the reduction in kappa number coupled to the release of reducing sugars suggest the dissociation of lignin-carbohydrate complex (LCC) from the pulp fibers by enzyme action (Khandeparkar and Bhosle 2007). Earlier studies with xylanases show a decrease in kappa number after treatment. The Antherobacter sp. MTCC 5214 xylanase showed $20 \%$ reduction in kappa number of kraft pulp after $2 \mathrm{~h}$ treatment (Khandeparkar and Bhosle 2007), while B. pumilus xylanase showed $14 \%$ reduction in kappa number of kraft pulp (Bim and Franco 2000). In the present study, we observed a better reduction $(23.8 \%)$ in kappa number after treatment with purified xylanase-sorbitol mix.

\section{SEM of xylanase treated pulp}

Scanning electron microscopy analysis of pulp fibers was carried out to observe the morphological changes after xylanase treatment. SEM images of untreated and xylanase treated pulp (Fig. 8a, b) showed change in morphology of pulp fibers after treatment with xylanase. The surface of untreated pulp fibers surface was smooth (Fig. 8a), whereas that of the treated fibers was rough (Fig. 8b). Further, the xylanase-treated image showed an increase in swelling, peeling and loosening of pulp fibers. These changes on the surface of xylanase treated pulps suggest hydrolysis of xylan in pulp (Fig. 8b). Similar observations on pulp fiber after enzyme treatment have been reported (Nagar et al. 2013).

\section{Conclusions}

The findings of the present study suggest that xylanase from B. amyloliquefaciens strain SK-3 was cellulase-free with estimated MW of $50 \mathrm{kDa}$. The optimum $\mathrm{pH}$ and temperature for the purified xylanase were $\mathrm{pH} 9.0$ and $50{ }^{\circ} \mathrm{C}$. The enzyme shows good activity retention under alkaline $\mathrm{pH}$. Enzyme activity was stimulated by $\mathrm{Mn}^{2+}$ and $\mathrm{Ca}^{2+}$ metal ions. The thermostability of the xylanase improved by 6.5 -fold at $70{ }^{\circ} \mathrm{C}$, after sorbitol addition. The xylanase produced by present strain showed better reduction of kappa number (23.8\%) compared to earlier studies. The sorbitol serves as a potential stabilizer for xylanase from B. amyloliquefaciens strain SK-3, which may be of commercial use in industries including pulp and paper industry.

Acknowledgements Authors are grateful to Director, CSIR-Indian Institute of Toxicology Research, Lucknow, for the support and 
encouragement. The authors acknowledge Department of Biotechnology, Government of India, New Delhi, for financial assistance under the RGYI Scheme (No. BT/PR6343/GBD/27/404/2012). We are also thankful to Dr. P. N. Saxena for his help in SEM studies. This work will be used by Sharad Kumar for partial fulfillment of the degree requirement for his doctoral research at Amity Institute of Biotechnology, Amity University Lucknow campus, Lucknow.

\section{Compliance with ethical standards}

Conflict of interest The authors declare that there is no conflict of interest.

Open Access This article is distributed under the terms of the Creative Commons Attribution 4.0 International License (http:// creativecommons.org/licenses/by/4.0/), which permits unrestricted use, distribution, and reproduction in any medium, provided you give appropriate credit to the original author(s) and the source, provide a link to the Creative Commons license, and indicate if changes were made.

\section{References}

Amore A, Parameswaran B, Kumar R, Birolo L, Vinciguerra R, Marcolongo L, Ionata E, La Cara F, Pandey A, Faraco V (2015) Application of a new xylanase activity from Bacillus amyloliquefaciens XR44A in brewer's spent grain saccharification. J Chem Technol Biotechnol 90:573-581

Bajaj BK, Manhas K (2012) Production and characterization of xylanase from Bacillus licheniformis P11 (C) with potential for fruit juice and bakery industry. Biocatal Agric Biotechnol 4:330-337

Bajaj BK, Sharma M, Sharma S (2011) Alkalistable endo $\beta-1,4-$ xylanase production from a newly isolated alkalitolerant Penicillium sp. SS1using agro-residues. 3Biotech 1:83-90

Bankeeree W, Lotrakul P, Prasongsuk S, Chaiareekij S, Eveleigh DE, Kim SW, Punnapayak H (2014) Effect of polyols on thermostability of xylanase from a tropical isolate of Aureobasidium pullulans and its application in prebleaching of rice straw pulp. Spring Plus 3:1-11

Barrow GI, Feltham RKA (1993) Cowan and steel's manual for the identification of medical bacteria, 3rd edn. Cambridge University Press, New York

Bastawde K (1992) Xylan structure, microbial xylanases, and their mode of action. World J Microbiol Biotechnol 8:353-368

Bim MA, Franco TT (2000) Extraction in aqueous two-phase systems of alkaline xylanase produced by Bacillus pumilus and its application in kraft pulp bleaching. J Chromatogr B Biomed Sci Appl 743:349-356

Breccia JD, Sifieriz F, Baigori MD, Castro GR, Kaul RH (1998) Purification and characterization of a thermostable xylanase from Bacillus amyloliquefaciens. Enzyme Microb Technol 22:42-49

Costa SA, Tzanov T, Carneiro AF, Paar A, Gübitz GM, Cavaco-Paulo A (2002) Studies of stabilization of native catalase using additives. Enzyme Microb Technol 30:387-391

Cui L, Du G, Zhang D, Chen J (2008) Thermal stability and conformational changes of transglutaminase from a newly isolated Streptomyces hygroscopicus. Bioresour Technol 99:3794-3800

Dhiman SS, Sharma J, Battan B (2008) Industrial applications and future prospects of microbial xylanases: a review. BioResources 3:1377-1402
George SP, Ahmad A, Mb Rao (2001) A novel thermostable xylanase from Thermomonospora sp.: influence of additives on thermostability. Bioresour Technol 78:221-224

Gupta M (1991) Thermostabilization of proteins. Biotechnol Appl Biochem 14:1-11

Gupta S, Bhushan B, Hoondal G (2000) Isolation, purification and characterization of xylanase from Staphylococcus sp. SG-13 and its application in biobleaching of kraft pulp. J Appl Microbiol 88:325-334

Hongchen Z, Liu Y, Liu X, Wang J, Han Y, Lu F (2012) Isolation, purification, and characterization of a thermostable xylanase from a novel strain, Paenibacillus campinasensis G1-1. J Microbiol Biotechnol 22:930-938

Kamble RD, Jadhav AR (2012) Isolation, purification, and characterization of xylanase produced by a new species of Bacillus in solid state fermentation. Int J Microbiol. doi:10.1155/2012/ 683193

Kaya F, Heitmann JA, Joyce TW (2000) Influence of lignin and its degradation products on enzymatic hydrolysis of xylan. J Biotechnol 80:241-247

Khandeparkar R, Bhosle NB (2006) Isolation, purification and characterization of the xylanase produced by Arthrobacter sp. MTCC 5214 when grown in solid-state fermentation. Enzyme Microb Technol 39:732-742

Khandeparkar R, Bhosle NB (2007) Application of thermoalkalophilic xylanase from Arthrobacter sp. MTCC 5214 in biobleaching of kraft pulp. Bioresour Technol 98:897-903

Knob A, Carmona EC (2009) Purification and characterization of two extracellular xylanases from Penicillium sclerotiorum: a novel acidophilic xylanase. Appl Biochem Biotechnol 162:429-443

Kulkarni N, Shendye A, Rao M (1999) Molecular and biotechnological aspects of xylanases. FEMS Microbiol Rev 23:411-456

Kumar V, Satyanarayana T (2011) Applicability of thermo-alkalistable and cellulase-free xylanase from a novel thermo-haloalkaliphilic Bacillus halodurans in producing xylooligosaccharides. Biotechnol Lett 33:2279-2285

Lee CC, Kibblewhite-Accinelli RE, Smith MR, Wagschal K, Orts WJ, Wong DW (2008) Cloning of Bacillus licheniformis xylanase gene and characterization of recombinant enzyme. Curr Microbiol 57:301-305

Lemos JLS, Bon EPS, Santana MFE, Junior NP (2000) Thermal stability of xylanases produced by Aspergillus awamori. Braz J Microbiol 31:206-211

Lineweaver H, Burk D (1934) The determination of enzyme dissociation constants. J Am Chem Soc 56:658-666

Lowry OH, Rosenbrough NJ, Farr AL, Randall RJ (1951) Protein measurement with the folin-phenol reagent. J Biol Chem 193:265-275

Mander P, Choi YH, Pradeep GC, Choi YS, Hong JH, Cho SS, Yoo CJ (2014) Biochemical characterization of xylanase produced from streptomyces sp CS624 using an agro residue substrate. Process Biochem 49:451-456

Menon G, Mody K, Keshri J, Jha B (2010) Isolation, purification, and characterization of haloalkaline xylanase from a marine Bacillus pumilus strain, GESF-1. Biotechnol Bioprocess Eng 15:998-1005

Miller GL (1959) Use of dinitrosalicylic acid for the determination of reducing sugar. Anal Chem 31:426-428

Mishra M, Thakur IS (2010) Isolation and characterization of alkalotolerant bacteria and optimization of process parameters for decolorization and detoxification of pulp and paper mill effluent by Taguchi approach. Biodegradation 21:967-978

Morrison D, Van Dyk JS, Pletschke BI (2011) The effect of alcohols, lignin and phenolic compounds on the enzyme activity of Clostridium cellulovorans XynA. BioResources 6:3132-3141 
Nagar S, Mittal A, Gupta VK (2012) Enzymatic clarification of fruit juices (apple, pineapple, and tomato) using purified Bacillus pumilus SV85S xylanase. Biotechnol Bioprocess Eng 17:1165-1175

Nagar S, Jain RK, Thakur VV, Gupta VK (2013) Biobleaching application of cellulase poor and alkali stable xylanase from Bacillus pumilus SV-85S. 3Biotech 3:277-285

Nakamura S, Wakabayashi K, Nakai R, Aono R, Horikoshi K (1993) Purification and some properties of an alkaline xylanase from alkaliphilic Bacillus sp. strain 41M-1. Appl Environ Microbiol 59:2311-2316

Park I, Cho J (2010) Partial characterization of extracellular xylanolytic activity derived from Paenibacillus sp. KIJ1. Afr J Microbiol Res 4:1257-1264

Patel R, Grabski A, Jeffries T (1993) Chromophore release from kraft pulp by purified Streptomyces roseiscleroticus xylanases. Appl Microbiol Biotechnol 39:405-412

Raj A, Kumar S, Singh SK (2013a) A highly thermostable xylanase from Stenotrophomonas maltophilia: purification and partial characterization. Enzyme Res. doi:10.1155/2013/429305

Raj A, Kumar S, Singh SK, Kumar M (2013b) Characterization of a new Providencia sp. strain $\mathrm{x} 1$ producing multiple xylanases on wheat bran. Sci World. doi:10.1155/2013/386769
Sanghi A, Garg N, Gupta VK, Mittal A, Kuhad RC (2010) One step purification and characterization of a cellulase free xylanase produced by alkalophilic Bacillus subtilis ASH. Braz J Microbiol 41:467-476

Sá-Pereira P, Costa-Ferreira M, Aires-Barros MR (2002) Enzymatic properties of a neutral endo-1, 3 (4)- $\beta$-xylanase Xyl II from Bacillus subtilis. J Biotechnol 94:265-275

Sharma M, Mehta S, Kumar A (2013) Purification and characterization of alkaline xylanase secreted from Paenibacillus macquariensis. Adv Microbiol 3:32-41

TAPPI (1985) Tappi method T $236 \mathrm{~cm}-8$ in Kappa number of pulp. Tappi Press, Atlanta

Tseng MJ, Yap MN, Ratanakhanokchai K, Kyu KL, Chen ST (2002) Purification and characterization of two cellulase free xylanases from an alkaliphilic Bacillus firmus. Enzyme Microb Technol 30:590-595

Yang V, Zhuang Z, Elegir G, Jeffries T (1995) Alkaline-active xylanase produced by an alkaliphilic Bacillus sp. isolated from kraft pulp. J Ind Microbiol 15:434-441 